MEDICAL HISTORY

\title{
The first black doctors and their influence in South Africa
}

\begin{abstract}
B M Mayosi
Prof. Bongani Mayosi is Head of the Department of Medicine at Groote Schuur Hospital and the Faculty of Health Sciences, University of Cape Town, South Africa. He qualified in medicine from the University of KwaZulu-Natal in Durban, trained in internal medicine and cardiology in Cape Town, and graduated with a DPhil in genetics from Oxford University. His research interests include the genetics of cardiovascular traits, treatment of tuberculous pericarditis and prevention of rheumatic fever.
\end{abstract}

Corresponding author: B M Mayosi (bongani.mayosi@uct.ac.za)

The early black doctors who qualified from foreign medical schools between 1883 and 1940 were pioneers in the history of South Africa. They made seminal contributions to the struggle against colonialism and apartheid, established the principle of fighting against racism in healthcare through the courts, and were trailblazers in academic medicine. They have bequeathed a remarkable legacy to the new South Africa.

S Afr Med J 2015;105(8):635-636. DOI:10.7196/SAMJnew.7821

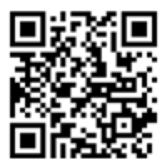

Before 1940, there were no opportunities for training in medicine in South Africa (SA) for people who were not white. The University of the Witwatersrand (Wits) took the first black medical students in 1941, and was followed shortly by the University of Cape Town (UCT). ${ }^{[1]}$ Before 1940, training was possible overseas either through funding from the church for many black Africans or from family resources for coloured and Indian South Africans.

\section{Early black medical doctors}

William Anderson Soga was the first black medical doctor in SA. ${ }^{[2]}$ He was the son of Tiyo Soga from Tamarha near Butterworth in Transkei, who was ordained as the first black SA minister of religion in the United Presbyterian Church of Scotland on 10 December 1856. Soga qualified in medicine from Glasgow in 1883 - about 30 years before the creation of the medical school in Cape Town, and 60 years before UCT and Wits considered black people fit for admission to their hallowed halls. Let us not forget that UCT practised a pernicious form of racism in which local black African students were not admitted to study medicine until about 100 years after Soga's graduation from Glasgow.

Like his father, Dr Soga was ordained as a minister (in 1885). He was licensed to practise in the Cape from 1890, and worked as a medical missionary at the Miller Mission in Eliotdale, Bomvanaland. He started private practice in the same area in 1904 and worked there until his death in 1912. Soga's example was followed by John Mavuma Nembula, who graduated with the degree Doctor of Medicine from Chicago in 1887, and Abdullah Abdurahman, who earned the Scottish Triple in 1893.

Nembula was born in Amanzimtoti, Natal, and educated at Adams Mission Station before he was taken to the USA by American missionaries to translate the Bible into Zulu. He commenced practice as a district surgeon at Umsinga in 1889 and ran a multiracial practice in nearby Pomeroy. He died of tuberculosis in 1897 at the age of 36.

Abdurahman practised in Cape Town between 1895 and 1929. During this time, he fought for better living conditions for black people as a Cape Town city councillor. His daughter Cissie married Abdul Hamid Gool, who qualified as a doctor from London in 1910, and his brother Ismail Abdurahman qualified as a doctor from
Glasgow in 1915. Another daughter, Waradea Abdurahman, became the first black woman to qualify as a doctor in SA (Glasgow, 1927).

The dynastic tendency of the first generation of black doctors was also evident among the Sogas. Alexander R B Soga, son of William Anderson, became the seventh black doctor in SA (Glasgow, 1912). Alexander Soga started his practice in Eliotdale, where his father had worked, and subsequently established a private practice in Idutywa in the Transkei.

\section{The next generation}

Whereas only three black doctors had qualified in the final 20 years of the 19th century, there were 29 who qualified from UK and US medical schools between 1900 and 1940, including luminaries such as James Moroka (Edinburgh, 1918), Silas Modira Molema (Glasgow, 1919), Alfred Bitini Xuma, with dual American (1920) and Scottish (1926) qualifications, Monty Naicker and Yusuf Dadoo (both Edinburgh, 1934).

Moroka and Xuma became successive presidents of the African National Congress (ANC) in the 1940s and have suburbs in Gauteng named after them - Kwa Xuma in Springs and Moroka in Soweto. Naicker revived the Natal Indian Congress (NIC), and Dadoo was initially the president of the Transvaal Indian Congress (TIC) before he became a leader of the South African Communist Party.

\section{Political contributions}

The first generation of black doctors made seminal and lasting contributions in at least three areas. The first was their political contribution to the non-racial struggle against apartheid. The famous 'Three Doctors' Pact' bears testimony to their foundational role in the new SA. A 'Joint Declaration of Cooperation' was signed by Xuma, President of the ANC, Naicker, President of the NIC, and Dadoo, President of the TIC, on 9 March 1947. ${ }^{[3]}$ The Doctors' Pact was significant: it provided the basis for unity among Africans and Indians and the principle of non-racialism that was to define the anti-apartheid struggle from the 1950s onwards, and the call for 'a vigorous campaign to be launched immediately' inspired the Defiance Campaign of the early 1950s that signalled the change in the tempo of the anti-apartheid struggle from a series of deputations to the Queen pleading for mercy to direct political action against unjust laws. 
The irony of the change and radicalisation of the anti-apartheid struggle is that Moroka and Xuma were faced with a stark choice between political activism carrying the risk of imprisonment, and the continuation of their lucrative medical careers. Indeed, during the Defiance Campaign, Moroka was to testify against his comrades in the ANC and escape prison. Nelson Mandela said that Moroka 'was unwilling to jeopardise his medical career and fortune for his political beliefs'.

Xuma also fell on his sword. He opposed the 1949 Programme of Action of the ANC Youth League, which envisaged a campaign of mass mobilisation, and resigned from the ANC, continuing to practise in Sophiatown. Mandela commented that 'his medical practice took precedence ... he made it clear that he was a doctor with a wide and prosperous practice that he would not jeopardise by going to prison'

There was, however, a new generation of black doctors who had qualified from Wits in the 1940s and 1950s, such as Wilson Conco, Dilizintaba Mji, Ntatho Motlana and James Njongwe, who joined Mandela in the Defiance Campaign and pursued the new radical agenda of the ANC, thus taking over the baton of political leadership from the first generation of ANC doctors.

Molema's story represents the second major contribution of the early black doctors to our history. He commenced practice in Mafikeng in 1922, and ran a subsidiary practice in Johannesburg. He had a multiracial practice and observed the custom of the time that provided for separate entrances for white and black patients. Molema's practice of liberally prescribing medicine (much liked by his black patients) also found favour among Afrikaner patients, who referred to him as 'die dokter van die groot bottel' (the doctor of the large bottle). ${ }^{[1]}$

In 1927, an incident occurred that I believe was the trailblazer for the health-for-all campaign in SA. White nurses resigned after Molema admitted some of his white private patients to Victoria Hospital in Mafikeng. He did not take this affront to decent healthcare for his patients lying down - he took legal action, and won the case for access of his patients to appropriate care unencumbered by racism.

\section{Academic achievements}

Finally, the first generation of black doctors were not devoid of academic ability. Dr William Anderson Soga was not only the first black doctor in SA, but he also wrote a Doctor of Medicine thesis after 10 years of practice in Bomvanaland. ${ }^{[2]}$ The thesis has remarkable aspects. First, it emphasised the role of climate, nutrition and housing in the genesis of ill-health among the Bomvana people Soga foresaw the role of climate change in health and disease that has become a major subject of study and controversy in our time. Second, he wrote about the epidemiology of local diseases, including the persisting problems of rheumatic fever, tuberculosis and leprosy. Finally, he provided a mixed assessment of the effectiveness of traditional medicine, praising the methods used to treat fracture but lambasting the wily and deceptive ways of traditional diviners. ${ }^{[2]}$
Wilson Zamindlela Conco was a promising successor to William Anderson Soga as the second black academic physician in SA. He was a brilliant medical student who qualified from Wits at the top of his class in 1948. His appointment as demonstrator in histology at Wits provoked a protest among National Party MPs that led to his demotion to demonstrator to black students only. ${ }^{[1]}$ The acquiescence of Wits to academic racism was a harbinger of the Archie Mafeje affair at UCT in 1969, and closed the doors to aspirant black scholars in our university system for decades.

\section{A remarkable legacy}

The first generation of black doctors have bequeathed to us a great example that is as relevant to the new SA as it was during their time. Rudolf Ludwig Carl Virchow, the German pathologist and politician, said that medicine is a social science, and politics is nothing other than medicine on a large scale. Our generation of medical doctors accepts the responsibility to play a public role, which may require direct political action from time to time. ${ }^{[4]}$ This we have done, for example when our politicians attempted to cut beds at Groote Schuur Hospital ${ }^{[5]}$ - such public action has ensured that tertiary medicine is recognised as a legitimate component of an effective national health system. ${ }^{[6]}$

The courts that were used effectively by Silas Modiri have been a powerful weapon in ensuring that the government of Thabo Mbeki provided antiretroviral therapy against its own wishes, and that drug companies are forced to provide lifesaving medication at a cost that poor people can afford.

Finally, we are building on the remarkable Doctor of Medicine degree of William Anderson Soga by raising a new generation of scholars in medicine on a large scale. We have started a multitude of schemes to provide opportunities for health professionals to become researchers and scholars as good as any in the world. One ambitious project is to produce $1000 \mathrm{PhDs}$ in medicine over the next ten years. ${ }^{[7]}$ This and other plans are beginning to bear fruit, and promise to usher SA on to the high road of research and innovation in healthcare and help to overcome the formidable health problems of the people of Africa.

\footnotetext{
Digby A. Early black doctors in South Africa. Journal of African History 2005;46(3):427-454. [http:// dx.doi.org/10.1017/S0021853705000836]

Digby A. On the notable thesis of William Anderson Soga, the first black doctor in South Africa. S Afr Med J 2007;97(5):345-346.

'Three Doctors' Pact', March 9 1947. http://www.sacp.org.za/docs/history/dadoo-45.html (accessed 15 March 2015).

4. Bateman C. Academic health complexes bleeding in 'no man's land'. S Afr Med J 2010;100(1):17-19.

5. Caelers D. Docs sticking to their guns in cuts row. 2007. http://www.iol.co.za/news/south-africa/ docs-sticking-to-their-guns-in-cuts-row-1.316699?ot=inmsa.ArticlePrintPageLayout.ot (accessed 18 February 2015)

February 2015).
Mayosi BM, Benatar SR. Health and health care in South Africa - 20 years after Mandela. N Engl J Med

6. Mayosi BM, Benatar SR. Health and health care in South Africa - 20 years after Mandela. N Engl J Med
2014;371(14):1344-1353. [httt://dx.doi.org/10.1056/NEJMsr1405012]
7. Nordling L. South Africa invests in health research training. 2012. http://blogs.nature.com/

news/2012/04/south-africa-invests-in-health-research-training.html (accessed 16 March 2015).
}

Accepted 20 March 2015 